\title{
Contrasting effects of long term versus short-term nitrogen addition on photosynthesis and respiration in the Arctic
}

\author{
Martine J. van de Weg, Gaius R. Shaver, Verity G. Salmon
}

This article was accepted for publication in Plant Ecology.

van de Weg, M.J., Shaver, G.R., and Salmon, V.G. 2013. Contrasting effects of long term versus short-term nitrogen addition on photosynthesis and respiration in the Arctic. Plant ecology. 214(10): 1273-1286. Available from DOI:

http://dx.doi.org/10.1007/s11258-013-0250-6

The final publication is available at Springer via

http://dx.doi.org/10.1007/s11258-013-0250-6 
1 Title: Contrasting effects of long term vs. short-term nitrogen addition on photosynthesis and

2 respiration in the Arctic.

3

4 Authors: Martine J. van de Weg ${ }^{1,2}$, Gaius R. Shaver ${ }^{2}$ and Verity G. Salmon ${ }^{3}$

5

6 Author addresses:

7 1. Amsterdam Global Change Institute, Vrije Universiteit Amsterdam, De Boelenlaan 1085, 1081 HV Amsterdam.

2. The Ecosystem Centre, Marine Biological Laboratory, 7 MBL Street, Woods Hole, Massachusetts, USA.

3. Department of Biology, University of Florida, Gainesville, Florida, USA.

12

13 Corresponding author details:

14 Martine J. van de Weg

15 E-mail: m.j.vande.weg@vu.nl

16 Tel: 0031-205986877

17

18

19 Word count (minus abstract and references): 5341

20 Word count abstract: 247

21 
Abstract

24 We examined the effects of short ( $<1$ to 4 years) and long-term (22 years) nitrogen $(\mathrm{N})$ and/or phosphorus (P) addition on the foliar $\mathrm{CO}_{2}$ exchange parameters of the arctic species Betula nana and Eriophorum vaginatum in northern Alaska. Measured variables included: the carboxylation efficiency of Rubisco $\left(\mathrm{V}_{\mathrm{cmax}}\right)$, electron transport capacity $\left(\mathrm{J}_{\max }\right)$, dark respiration $\left(\mathrm{R}_{\mathrm{d}}\right)$, chlorophyll $a$ and $b$ content $(\mathrm{Chl})$, and total foliar $\mathrm{N}(\mathrm{N})$. For both $B$. nana and $E$. vaginatum, foliar $\mathrm{N}$ increased by $20-50 \%$ as a consequence of 1 to 22 years of fertilisation, respectively, and for $B$. nana foliar N increase was consistent throughout the whole canopy. However, despite this large increase in foliar N, no significant changes in $V_{c \max }$ and $J_{\max }$ were observed. In contrast, $R_{d}$ was significantly higher ( $\left.>25 \%\right)$ in both species after 22 years of $\mathrm{N}$ addition, but not in the shorter-term treatments. Surprisingly, Chl only increased in both species the first year of fertilisation (i.e. the first season of nutrients applied), but not in the longer-term treatments. These results imply that: 1) Under current (low) $\mathrm{N}$ availability, these Arctic species either already optimize their photosynthetic capacity per leaf area, or are limited by other nutrients; 2) Observed increases in Arctic NEE and GPP with increased nutrient availability are caused by structural changes like increased leaf area index, rather than increased foliar photosynthetic capacity and 3) Short-term effects (1-4 years) of nutrient addition cannot always be extrapolated to a larger time scale, which emphasizes the importance of long-term ecological experiments.

Keywords: nitrogen use efficiency, fertilisation, LTER, Alaska, chlorophyll, canopy, leaf mass per area 


\section{Introduction}

The productivity of Arctic tundra ecosystems is limited by cold temperatures, short growing seasons and low nutrient (nitrogen $(\mathrm{N})$ and phosphorus $(\mathrm{P})$ ) supply (Shaver and Chapin 1980, 1986; Chapin et al. 1995). Although the $\mathrm{N}$ deposition rates in the Arctic are relatively low compared to industrialized and temperate regions in the Northern hemisphere, $\mathrm{N}$ deposition has increased with the global rise in anthropogenic $\mathrm{N}$ emissions the past century (Bobbink et al. , 2010). Furthermore, warming of the Arctic is expected to increase $\mathrm{N}$ availability, as warming experiments in Alaska have shown increased available $\mathrm{N}$ though increased mineralization rates, or through permafrost thawing (e.g. Johnson et al. 2000; Shaver et al. 2001; Keuper et al. 2012). Additionally, studies on Arctic watersheds already have observed higher export rates of different $\mathrm{N}$ forms (i.e. nitrate, ammonium, dissolved organic nitrogen) most likely as a consequence of warming of tundra and increased thawing of permafrost (Frey et al. 2007; McClelland et al. 2007). Given the anticipated environmental change, $\mathrm{N}$ availability in the Arctic is expected to increase in the coming century.

On a plot stand scale, it has been well established that long-term $\mathrm{N}$ (together with $\mathrm{P}$ ) addition in Arctic tundra increases the biomass, leaf area index (LAI), gross ecosystem production and ecosystem respiration (Shaver et al. 1998; Boelman et al. 2003; Mack et al. 2004). Furthermore, long-term $\mathrm{N}$ and $\mathrm{P}$ addition causes a shift in species composition, with an increase in shrub cover, while bryophytes and forbs are reduced (Shaver and Chapin, 1991 1995; Bret-Harte et al. 2002; Hobbie et al. 2002 Zamin and Grogan, 2012). Less is known, however, about the long-term effects of $\mathrm{N}$ and $\mathrm{P}$ addition on dark respiration $\left(\mathrm{R}_{\mathrm{d}}\right)$ and net photosynthesis $\left(A_{n e t}\right)$ at the leaf level. Moreover, the effects of increased $\mathrm{N}$ on the more fundamental determinants of photosynthetic capacity, the maximum carboxylation velocity $\left(\mathrm{V}_{\mathrm{cmax}}\right)$ of the enzyme ribulose-1,5-bisphosphate carboxylase/oxygenase (Rubisco) and the 
maximum rate of electron transport $\left(\mathrm{J}_{\max }\right)$, remain minimally explored for tundra vegetation. Maximum $A_{\text {net }}, V_{\text {cmax }}, J_{\max }$ and $R_{d}$ are tightly related to $\mathrm{N}$ content, mainly because of the high investment of $\mathrm{N}$ in the $\mathrm{C} 3$ photosynthetic apparatus (Field and Mooney, 1986; Evans, 1989), and high involvement of $\mathrm{N}$-rich proteins in maintenance respiration for protein turnover (Penning De Vries 1975). Previous N and/or P addition experiments in Arctic tundra (lasting 1-4 years) showed a diverse array of effects on (maximum) $A_{n e t}$ and $R_{d}$ for different species. For example, Matthes-Sears et al. (1988) found an increase of total foliar $\mathrm{N}$ after four years of nutrient addition with $\mathrm{N}$ and $\mathrm{P}$, but this had no consequence for $\mathrm{A}_{\text {net }}$ in Betula nana and Salix pulchra. This is similar to a recent finding of Heskel et al. (2012) who found no effect of four years of $\mathrm{N}$ and $\mathrm{P}$ addition on maximum $\mathrm{A}_{\text {net }}$ for B. nana and Eriophorum vaginatum, but increased levels of $R_{d}$ in the Alaskan tundra. Contrastingly, Oberbauer et al. (1989) found higher rates of maximum $\mathrm{A}_{\text {net }}$ after one and two years of NPK fertilizer in B. nana and Ledum palustre (but not in Carex biggelowii), while Chapin and Shaver (1996) similarly found higher foliar $\mathrm{N}$ and maximum $\mathrm{A}_{\text {net }}$ values in $B$. nana and $E$. vaginatum after four years of $\mathrm{N}$ and $\mathrm{P}$ addition, but not in L. palustre and Vaccinium vites-ideae.

Overall, the effects of $\mathrm{N}$ and/or $\mathrm{P}$ addition to tundra vegetation on foliar gas exchange parameters are not straightforward. Furthermore, field nutrient addition experiments that exceed 5 or 10 years of nutrient addition are rare, not only in Arctic tundra. It is questionable whether results regarding maximum $\mathrm{A}_{\text {net }}$ and $\mathrm{R}_{\mathrm{d}}$, or the proportional investment of $\mathrm{N}$ in the 94 photosynthetic apparatus, can extrapolated from a relatively small number of years to a prolonged period of elevated nutrient supply (> 20 years). Whether the photosynthetic nitrogen use efficiency (PNUE) changes after long periods of increased $\mathrm{N}$ supply is of particular interest, since in increasingly more vegetation models or up-scaling exercises the parameters $\mathrm{V}_{\mathrm{cmax}}$ and $\mathrm{J}_{\max }$, as well as $\mathrm{R}_{\mathrm{d}}$, are scaled by the amount of foliar $\mathrm{N}$ (Friend et al. 


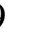
2009; Zaehle and Dalmonech 2011). Therefore, if the PNUE or $\mathrm{R}_{\mathrm{d}}-\mathrm{N}$ relationships change with changes in $\mathrm{N}$ availability or $\mathrm{N}$, this might have consequences for the accuracy of predictions of future carbon uptake. Finally, most of the nutrient addition studies mentioned above only included fully sunlit leaves, from the top of the tundra canopy. In general, foliar $\mathrm{N}$ on an area basis ( $\left.\mathrm{N}_{\text {area }}\right)$, as well as $\mathrm{V}_{\text {cmax- }}$ and $\mathrm{J}_{\max }$ on an area basis decline with decreasing light throughout a canopy, though the pattern of the foliar traits throughout the canopy does not follow the patterns of decrease in irradiance in 1:1 proportion (e.g. Meir et al. 2002; Niinemets 2007). Whether the investment of foliar $\mathrm{N}$ in the photosynthetic apparatus throughout the canopy in the Arctic differs under fertilized and an unfertilized condition has received little attention.

In this study we investigated the effects of different durations and rates of $\mathrm{N}$ and/or $\mathrm{P}$ fertilizer addition on the foliar $\mathrm{CO}_{2}$ exchange parameters of the two common Arctic tundra species B. nana and E. vaginatum. More specifically, the aims of this study were: 1) to investigate the effects of short and long term $\mathrm{N}$ addition on the foliar $\mathrm{CO}_{2}$ exchange parameters $\mathrm{V}_{\mathrm{cmax}}, \mathrm{J}_{\max }$, and $\mathrm{R}_{\mathrm{d}}$, as well as foliar $\mathrm{N}$, the foliar chlorophyll content (Chl) and leaf mass per area (LMA); 2) to investigate whether the relative $\mathrm{N}$ investment in $\mathrm{V}_{\mathrm{cmax}}, \mathrm{J}_{\max }$, $\mathrm{R}_{\mathrm{d}}$ and chlorophyll changes with different nutrient addition amount and different durations, and 3) to investigate whether the relative $\mathrm{N}$ investment in these $\mathrm{CO}_{2}$ exchange parameters differs at different canopy positions in fertilized and unfertilized tundra.

\section{Methods}

\section{Research area and species}

For this study we sampled two $\mathrm{N}$ and $\mathrm{P}$ addition experiments that are located in moist acidic tundra within the Arctic Long Term Ecological Research (LTER) site in the northern 
124 foothills of the Brooks Range, Alaska $\left(68^{\circ} 38^{\prime} \mathrm{N}, 49^{\circ} 43^{\prime} \mathrm{W}\right.$, elevation $\left.720 \mathrm{~m}\right)$. In both

125 experiments, nutrients are added to plots of $50 \mathrm{~m}^{2}$, as $\mathrm{NH}_{4} \mathrm{NO}_{3}$ and $\mathrm{P}_{\text {as }} \mathrm{P}_{2} \mathrm{O}_{5}$ every spring

126 following snow melt. Site 1 was installed in 1988, and details can be found in Bret-Harte et

127 al. (2001). From Site 1 the control (CT), N addition, $\mathrm{P}$ addition and $\mathrm{N}$ and $\mathrm{P}$ addition (NP)

128 treatments were used, with all treatments replicated in four blocks (Table 1). Site 2 was

129 installed in 2007, approximately $150 \mathrm{~m}$ south of Site 1 , and includes a range of quantities of

$130 \mathrm{~N}+\mathrm{P}$ addition (up to $10 \mathrm{~g} \mathrm{~N} \mathrm{~m}^{-2} \mathrm{yr}^{-1}$ ), with $50 \mathrm{~m}^{-2}$ plots which are replicated in four blocks as

131 well. From Site 2 the treatments that receive respectively 5 and $10 \mathrm{~g} \mathrm{~N} \mathrm{~m}^{-2} \mathrm{yr}^{-1}$ were selected

132 for this study, together with the accompanying control treatment (Table 1). Additionally, we

133 added a very short term $\mathrm{N}+\mathrm{P}$ fertilisation treatment to Site 2 . For this we installed four extra 1

$134 \mathrm{~m}^{2}$ plots to which $10 \mathrm{~g} \mathrm{~m}^{-2} \mathrm{~N}_{\text {and }} 5 \mathrm{~g} \mathrm{P} \mathrm{m}^{-2}$ was added on 30 May 2010 (Table 1).

135 The two species included in the study are the dwarf shrub Betula nana $\mathrm{L}$. and the

136 sedge Eriophorum vaginatum L., which are common throughout the whole Arctic region

137 (Britton, 1966). These two species were chosen because they were both abundant enough in

138 the control and nutrient addition plots from both experimental sites to sample for this study,

139 as in particular many evergreen species have decreased in (relative) abundance in the NP

140 plots of Site 1 (Gough et al. , 2012).

141

142 Experimental design

143 Gas exchange measurements were conducted on fully sun-lit leaves that were

144 collected from all of the research plots in Table 1 between 5 and 15 July 2010 (i.e. around the

145 peak of the growing season). Per species, treatment, and plot, two $A-C_{i}$ curves (measuring

146 maximal photosynthesis rates at a range of intercellular $\mathrm{CO}_{2}$ ) were performed, leading to 8

147 replicates per treatment and 64 measurements in total for each species. For the E. vaginatum,

148 6-10 leaves were used and measurements took place between 8-15 July 2010 for site 1 and 
149 between 5-15 July 2010 for site 2. For B. nana, 3-4 mature leaves attached to the twig were

150 used and the measurements for site 1 took place between 6-8 July 2010, and between 5-6 July

1512010 for site 2. Furthermore, for B. nana, the respiration rate of the corresponding twig part

152 that had been in the cuvette was measured afterwards, in order to correct the values from gas

153 exchange measurements. In addition, for both species the gas exchange measurements were

154 spread in a way that CT and nutrient addition samples were alternated throughout the day and

155 per photosynthesis system (see below or description of the gas exchange measurements).

156 Although this resulted in a not-complete random design, it avoided one of the treatments

157 being measured in a cluster in time or per photosynthesis system.

$158 \quad$ Between 10 and 30 July in 2011, we additionally measured foliar gas exchange on $B$.

159 nana leaves that were growing at different light regimes (i.e. the top, middle and bottom of

160 the canopy) from a CT and NP plot at Site 1 (Table 1). The light regime of the three canopy

161 positions were characterized using three quantum sensors (LI-90 Li-Cor Inc, Lincoln, USA)

162 that were placed at different canopy positions in both the CT and NP. Diurnal relative

163 photosynthetic active radiation (PAR) and average PAR was calculated using the average

164 photon flux density logged every 10 minutes (CR1000X, Campbell Scientific Ltd, Logan,

165 UT, USA) throughout the month long measurement period (Fig. 1). We sampled 6 replicates

166 of twigs with 3-4 leaves positioned around each of the quantum sensors (i.e. these leaves

167 were experiencing the same light regime) for gas exchange measurements, leading to 36

168 samples in total.

169

170 Gas exchange measurements

171 For the measurements in 2010, three open portable photosynthesis system (Li-Cor 6400, Li-

172 Cor Inc, Lincoln, USA), fitted with LED light sources (6400-02B Red/Blue Light Source, Li-

173 Cor, Inc, Lincoln, USA), were used for the $A-C_{\mathrm{i}}$ curves, following the procedural guidelines 
174 in Long and Bernacchi (2003). The $\mathrm{CO}_{2}$ concentrations inside the chamber ranged from 50 to $2000 \mathrm{ppm}$, and leaf temperature was set at $20{ }^{\circ} \mathrm{C}$ (average $\mathrm{T}_{\text {leaf }}$ was $20.1{ }^{\circ} \mathrm{C} \pm 0.05, \mathrm{n}=$ 128). Gas exchange measurements were conducted only between 10:00-18:00, to avoid any diurnal artefacts on leaf functioning. In the field, B. nana branches and E. vaginatum leaves were detached and immediately re-cut under water in the field, in order to reconstitute the water column. The sample was subsequently brought to the Toolik Field Station lab (at $\sim 1$ $\mathrm{km}$ distance) in order to start the measurements. This method, as opposed to conducting the A- $\mathrm{C}_{\mathrm{i}}$ curves in the field on attached leaves and twigs, limited trampling of the vegetation in the long-term nutrient addition plots and it avoided taking the sensitive photosynthesis systems out in unfavourable weather. Most importantly, conducting the gas exchange measurements in the field station lab enabled us to do this at nearly the same temperatures $\left(20^{\circ} \mathrm{C}\right)$, since the Li-Cor 6400 can control the leaf chamber temperature only within a limited range from ambient temperatures. Tests on non-detached and attached branches and leaves showed the shape or values of the $\mathrm{A}-\mathrm{C}_{\mathrm{i}}$ curves stayed the same before and after detachment.

188 Following the $\mathrm{A}-\mathrm{C}_{\mathrm{i}}$ curves, $\mathrm{R}_{\mathrm{d}}$ was measured, after keeping the leaf in darkness for a

189 minimum of 20 minutes to avoid transient changes in $\mathrm{CO}_{2}$ release associated with post-

190 illumination changes in metabolism (Azcón- Bieto and Osmond 1983). Gas exchange measurements made in 2011 followed the same procedures though the Li-Cor 6400 was fitted with a lighted conifer chamber (6400-22L, Li-Cor, Inc, Lincoln, USA).

After the gas exchange measurements, leaf area was measured using a desktop scanner and Winfolia software (Regent Instruments Inc, Canada). The leaves were then dried to a constant weight at $60{ }^{\circ} \mathrm{C}$ and weighed. Subsequently, the leaves were ground and

197 Analyzer (LECO Corporation, U.S.A.). The leaf mass per area (LMA) was calculated by 
combining the leaf area and leaf dry weight measurement and the LMA values were used to convert mass-based leaf parameters area-based ones.

\section{$A-C_{i}$ response curve analysis}

202 We used a curve fitting routine (Sharkey et al. 2007) to analyse the $A-C_{i}$ curves to calculate

$203 \mathrm{~V}_{\mathrm{cmax}}$ and $\mathrm{J}_{\max }$ on a leaf area basis. The curve fitting is based on minimum least-squares was used in "R" (R Development Core Team 2008). The fits were obtained using the Farquhar biochemical model of leaf photosynthesis (Farquhar et al. 1980; von Caemmerer 2000). The enzymatic kinetic constants were taken from Table 1 in Sharkey et al. (2007), while the

207 parameters for the curvefiting to $20^{\circ} \mathrm{C}$ were scaled using temperature dependencies provided

208 by Bernacchi et al. (2001, 2002, and 2003).

\section{Chlorophyll analyses}

211 Chlorophyll content of the B. nana leaves was determined using leaf level reflectance

212 measurements, as the leaf tissue from the gas exchange measurements was not enough to

213 measure both foliar $\mathrm{N}$ and $\mathrm{Chl}$ from. Therefore, directly after the gas exchange measurements 214 and before drying, leaf level reflectance for each wavelength between 350 and $1100\left(\mathrm{R}_{350^{-}}\right.$

$215 \mathrm{R}_{1000}$ ) was measured with a field portable spectrometer (Unispec, PP Systems, Amherst MA, 216 USA) and its accompanying bifurcated fibre optic cable and leaf clip. A calibration curve for

217 leaf level reflectance and chlorophyll content ( $a$ and $b$ ) was made with a subset of 50 B. nana

218 leaves from the research site. From these leaves, chlorophyll was extracted with N,N-

219 dimethylformamide (DMF) and determined photospectrometrically as described in Porra et 220 al. (1989), after they were freeze dried and stored temporarily at $-80^{\circ} \mathrm{C}$. The $\mathrm{mSR} 705$ index

$221\left(\left(\mathrm{R}_{750}-\mathrm{R}_{445}\right) /\left(\mathrm{R}_{705}-\mathrm{R}_{445}\right)\right)$ and chlorophyll content were then used to create a calibration curve $222\left(P<0.0001, R^{2}=0.67\right)$. With this calibration curve we determined the chlorophyll content of 
223 the B. nana leaves from the gas exchange measurements based on leaf level reflectance. For

224 the E. vaginatum samples, the leaves were not suitable for leaf level reflectance

225 measurements (i.e. the leaf area did not fit in the leaf clip). Therefore, we collected a

226 representative subset of sunlit leaves from each plot $(n=4)$ and their chlorophyll content was

227 determined directly at the research station using a Tris/acetone solution for extraction agent,

228 as described by Sims and Gamon (2002).

229

230

Statistics

Statistical analyses were performed in R (R Development Core Team, 2008). There

232

233

234

235

236

237

\section{$238 \quad$ Results}

239

240

241

242

243

244

245

246

247

\section{Foliar nitrogen content}

Nutrient addition effects on foliar $\mathrm{N}$ were not consistent through time or across species. Addition of both $\mathrm{N}$ and $\mathrm{N}+\mathrm{P}$ increased $\mathrm{N}_{\text {area }}$ in the leaves of shrub $B$. nana with $42 \%$ after 4 and $\sim 50 \%$ after $>20$ years of fertilisation $(P<0.001$ and $P=0.002$, respectively), while no increase was observed after the first year of $\mathrm{N}+\mathrm{P}$ addition (Fig. 2). However, for the $B$. nana that had received only 4 years of nutrient addition, only the treatment that had received the highest dosage of $\mathrm{N}+\mathrm{P}$ for 4 years (F10) had a significantly higher $\mathrm{N}_{\text {area }}$ values $(P<0.05)$,

while $N_{\text {area }}$ was not significantly higher than the control in the treatment that received half the dosage of fertiliser (F05). Additionally, $\mathrm{N}_{\text {mass }}$ of B.nana was $20 \%$ lower than the control in 
248 the $\mathrm{P}$ only treatment $(P<0.05)$ for this species. For the sedge $E$. vaginatum there was no effect

249 of $\mathrm{N}$ and/or $\mathrm{P}$ addition when expressed on an area basis. However, $\mathrm{N}_{\text {mass }}$ for this species was

$2506 \%$ higher $(P<0.05)$ with $\mathrm{N}$ only and $15 \%$ higher with $\mathrm{N}+\mathrm{P}$ after $>20$ years $((P<0.01$, Fig.

251 2). For E. vaginatum, no significant influence of the short-term fertilisation on $\mathrm{N}_{\text {area }}$ or $\mathrm{N}_{\text {mass }}$

252 was found.

Foliar $\mathrm{CO}_{2}$ exchange parameters

Despite the increase in $\mathrm{N}_{\text {area }}$ as a result of $\mathrm{N}$ and $\mathrm{P}$ addition, there was no significant increase in $\mathrm{V}_{\mathrm{cmax}}$ in B. nana, for any length of nutrient addition (Fig. 3a and 3b). In contrast, B. nana $\mathrm{V}_{\mathrm{cmax}}$ in the $\mathrm{P}$-only treatment was $41 \%$ lower than in the $\mathrm{CT}$ treatment $(P<0.05)$. For

E. vaginatum, there was no significant difference observed in $\mathrm{V}_{\mathrm{cmax}}$ among the different treatments in Site 1 or 2 . A similar pattern was found for $\mathrm{J}_{\max }$; for both species there was no significant influence of nutrient addition on this parameter in either of the sites (Fig. 3c and 3d). In contrast to the photosynthetic parameters, $R_{d}$ was $50 \%$ higher for $B$. nana and $27 \%$ for E. vaginatum in the $\mathrm{N}+\mathrm{P}$ treatment in Site $1(P<0.05)$, but not for the $\mathrm{N}$-only treatment (Fig. 3e and 3f). Finally, no significant differences in $R_{\mathrm{d}}$ between treatments and the controls were found for E. vaginatum or B. nana in Site 2. ( $P=0.43$ and $P=0.27$, respectively).

\section{Chlorophyll and LMA}

The chlorophyll content on an area basis $\left(\mathrm{Chl}_{\text {area }}\right)$ was significantly higher for both species in the YR1 treatment compared with their controls $(P<0.05)$. In contrast, leaves from both species that had experienced nutrient addition for more than one season showed no significant increases or decreases in $\mathrm{Chl}_{\text {area }}$ (Fig. 4a and 4b). Similarly, for LMA only the

271 YR1 treatment in $E$. vaginatum was significantly lower than the control treatment $(P<0.05)$ 
272 (Fig. 4d), but no differences in LMA were found in other treatments for either of the

273 investigated species.

274

275

Different canopy positions

Because of the lower LAI at the CT plot, PAR levels at the bottom of the canopy was higher than at the bottom of the canopy in the N+P plot (Fig. 1), and it was not possible to collect leaves in the CT treatment that had been grown at the same low light levels as in the NP treatment). Therefore, 'bottom canopy' leaves from the CT treatment cannot be compared with 'bottom canopy' leaves from the N+P treatment directly. Taking all canopy positions together, however, leaves from the $\mathrm{N}+\mathrm{P}$ treatment had a higher foliar $\mathrm{N}$ than those from the control treatment both on a mass and area basis for the whole dataset $(P<0.001$ and $P=0.02$, respectively, Fig. $5 \mathrm{a}$ and $5 \mathrm{~b}$ Student's t-test). For the N+P treatment, the fully sunlit leaves had similar $\mathrm{N}_{\text {mass }}$ values to those growing at lower light levels in the canopy, but significantly higher LMA values (0.001, Fig. 5f). In contrast, no significant differences in LMA were

286 found in the CT treatment for the leaves from the different light levels. $\mathrm{Chl}_{\text {area }}$ did not differ

287 significantly between the treatments or between canopy positions (data not shown), but when expressed on a mass basis $\left(\mathrm{Chl}_{\text {mass }}\right)$, the leaves from the NP treatment that received the least PAR, had higher values than the top canopy leaves ( $P>0.039$ Fig. 5e, Student's t-test). $V_{\text {cmax }}$ did not differ between the $\mathrm{N}+\mathrm{P}$ or $\mathrm{CT}$ treatment for top canopy leaves, and the relationship

291 between irradiance and $\mathrm{V}_{\mathrm{cmax}}$ was similar for the $\mathrm{CT}$ and $\mathrm{N}+\mathrm{P}$ treatment. The low-light leaves

292 in the NP treatment had significantly lower $\mathrm{V}_{\mathrm{cmax}}$ values than the top canopy leaves $293(P=0.008$, Fig. 5c).

\section{Discussion}


is insensitive to increases in leaf level $\mathrm{N}$ in the Arctic tundra. This suggests that some Arctic species already maximize their photosynthetic capacity per leaf area under ambient nutrient availability, or that they get limited by other nutrients when foliar $\mathrm{N}$ increases. Consequently,

300 the relationship between $\mathrm{N}$ and $\mathrm{V}_{\mathrm{cmax}}$ or $\mathrm{J}_{\max }$ is not linear for the two common Arctic species studied here.

\section{Long term nutrient addition and foliar $N$}

With both a relatively short (4 years) and long duration of the $\mathrm{N}$ and $\mathrm{P}$ addition, $\mathrm{N}_{\text {area }}$ and $\mathrm{N}_{\text {mass }}$ increased in B. nana, and for E. vaginatum only on a mass basis. This is consistent with other short-term (1-3 year) Arctic nutrient addition studies that showed increases of foliar $\mathrm{N}$ (on either a mass or area basis) after $\mathrm{N}$ addition (Oberbauer et al. 1989; Chapin and Shaver 1996; Shaver et al. 2001; Heskel et al. 2012), though some did not find this trend (e.g. Van Heerwaarden et al. 2003). One difficulty with comparing nutrient addition studies is that some studies only include fully sun-lit leaves, while in others the $\mathrm{N}_{\text {area }}$ and $\mathrm{N}_{\text {mass }}$ represent an average of leaves from the whole canopy. The LAI and the presence of $B$. nana increase substantially in moist acidic tussock tundra after several years of $\mathrm{N}$ (and) P addition (Shaver et al. 2001; Street et al. 2007) and consequently, the bottom leaves in the canopy receive less PAR (Fig. 1). These lower PAR levels cause the lowest leaves in the canopy to have a lower LMA (Ellsworth and Reich 1993; Evans and Poorter 2001; Niinemets 2007; and Fig. 6d this study), and can consequently decrease the bottom canopy $\mathrm{N}_{\text {area }}$ values, although $\mathrm{N}_{\text {area }}$ was not

317 significantly lower than the top leaves in the $\mathrm{N}+\mathrm{P}$ treatment in our observations (Fig. 5b).

318 Nevertheless, if leaves of the whole $\mathrm{N}+\mathrm{P}$ canopy are included in an average $\mathrm{N}_{\text {area }}$ value, the

319 leaves from the bottom of the canopy (with lower $\mathrm{N}_{\text {area }}$ values) could skew canopy averages

320 of $\mathrm{N}_{\text {area }}$ to lower average numbers because they contain proportionally less canopy leaves than 
321 the average of a CT canopy. Indeed, for Alaskan tundra shrub communities, the amount of total $\mathrm{N}$ in a canopy does not increase linearly, but asymptotic with increasing LAI (van Wijk et al. 2005), which would result in lower average foliar N values at high LAI. Therefore, comparing only the top canopy leaves (which will have received the same PAR regime) between two treatments can be expected to show differences in foliar nutrients more obvious then when canopy averages are compared.

\section{Foliar $\mathrm{N}$ and $\mathrm{CO}_{2}$ exchange parameters}

Firstly, given the generally conservative ratio between $V_{c \max }$ and $J_{\max }($ Wullschleger 1993) it is not unexpected that both photosynthetic parameters show similar patterns with $\mathrm{N}_{\text {area }}$. It is more surprising that for both $B$. nana and $E$ vaginatum, no increase in $\mathrm{V}_{\mathrm{cmax}}$ or $\mathrm{J}_{\max }$ was observed in the leaves with higher foliar $\mathrm{N}$ values from the $\mathrm{N}$ addition plots (Fig. 3a-3d). In contrast, when foliar $\mathrm{N}$ is lower than under control conditions (in the $\mathrm{P}$ only treatment, Fig. 2), the photosynthetic parameters $\mathrm{V}_{\mathrm{cmax}}$ and $\mathrm{J}_{\max }$ are also lower (Fig. 3a and 3c). In other words, the relationship with $\mathrm{N}$ and photosynthetic parameters holds when $\mathrm{N}$ is decreased

336 from ambient conditions, but when it increases the relationship becomes non-linear until it

337 de-couples. In addition, the patterns of $\mathrm{V}_{\mathrm{cmax}}$ and $\mathrm{J}_{\max }$ throughout the $\mathrm{N}+\mathrm{P}$ and CT canopy overlap in an almost continuous pattern (Fig. 5c and 5d ), even though the leaves in the N+P treatment that received the least radiation had high $\mathrm{N}_{\text {area }}$ and $\mathrm{N}_{\text {mass }}$ values compared with the

340 leaves in the CT treatment (Fig. 5a and 5b). This shows how radiation levels are an important 341 determinant for the patterns of photosynthetic capacity throughout a canopy (Meir et al. 2002

342 2001; Niinemets, 2007), since even when foliar $\mathrm{N}$ is high, this $\mathrm{N}$ is not used for the

343 photosynthetic capacity when the average received levels of PAR are low.

344 Similarly, for both species no increase in Chl (Fig. 4a and 4b) was observed with $\mathrm{N}_{\text {area }}$ 345 increase, except for the first year of when the $\mathrm{N}+\mathrm{P}$ addition. This first-year increase in Chl 
346 did not coincide with an increase in $\mathrm{V}_{\mathrm{cmax}}$ or $\mathrm{J}_{\max }$, which could be a consequence of the first

347 year $\mathrm{N}$ and $\mathrm{P}$ addition (i.e. a transient short term effect where in the absence of previous

348 nutrient addition extra $\mathrm{N}$ first is invested in Chl). Like $\mathrm{V}_{\mathrm{cmax}}$ and $\mathrm{J}_{\max }$, the pattern of Chl

349 throughout the canopy (Fig. 5e) was overlapping between the CT and $\mathrm{N}+\mathrm{P}$ treatment, and the

350 increased $\mathrm{Chl}$ in the bottom canopy $\mathrm{N}+\mathrm{P}$ leaves can be attributed to lower irradiance levels,

351 rather than higher foliar N (Evans and Poorter 2001, Niinemets 2003).

352 The de-coupling of foliar with photosynthetic capacity contrasts with the studies 2-3

353 year N-addition studies from Oberbauer et al. (1989) and Chapin and Shaver (1996) who

354 found higher levels of maximum $\mathrm{A}_{\text {net }}$ after fertilisation in B. nana. However, both these

355 studies did not include measurements of the photosynthetic parameters $\mathrm{V}_{\mathrm{cmax}}$ an $\mathrm{J}_{\max }$, so there

356 is a chance their increase in maximum $\mathrm{A}_{\text {net }}$ is a consequence of changes in the stomatal

357 behaviour for example. Furthermore, de-coupling of foliar $\mathrm{N}$ and $\mathrm{V}_{\mathrm{cmax}}$ has also been

358 observed with long-term (9 years) NPK addition in a nutrient poor bog in Canada and after 15

359 years of nutrient addition to a temperate forest (Bauer et al. 2004), which make our results not

360 unlike those from other ecosystems. The decrease in PNUE suggest that under ambient, low-

361 nutrient conditions of the Arctic, the $\mathrm{N}$ investment in foliar C-uptake is already optimal on a

362 leaf level scale, perhaps because these species (B. nana and E. vaginatum) have evolved

363 under low $\mathrm{N}$ availability. Alternatively, scarcity of other nutrients such as $\mathrm{Mg}^{2+}$, could be

364 limiting the photosynthetic capacity in the leaves with high foliar N. For example, Manter et

365 al. (2005) observed an increase in Rubisco (the enzyme involved in the first major step of

366 carbon fixation) in fertilised Pseudotsuga menziesii seedlings, but similar to our findings, the

367 activity of this Rubisco decreased with increasing foliar N. This Rubisco inactivation was

368 linked to a decreased relative availability of $\mathrm{Mg}^{2+}$, which led to Mn-induced Rubisco

369 deactivation. Additionally, Heskel et al. (2012) observed an increase in chloroplast area in $E$.

370 vaginatum and $B$. nana after $\mathrm{N}+\mathrm{P}$ addition. Larger chloroplasts as a consequence of high $\mathrm{N}$ 
371

372

373

374

375

376

377

378

379

380

381

382

383

384

385

386

387

388

389

390

391

392

393

394

395

supply has been correlated with decreased Rubisco specific activity and PNUE in other species as well (Li et al. 2013), and is explained by a decreased ratio of mesophyll conductance to Rubisco content and a lower Rubisco specific activity. It is likely that in our study the increased foliar N lead to a similar pattern of increased Rubisco content with a reduced activity, with no increase in $\mathrm{V}_{\mathrm{cmax}}$ as a consequence.

It could be argued that the high dosages of $\mathrm{N}$ and $\mathrm{P}$ addition in our study (up to $10 \mathrm{~g}$ $\mathrm{m}^{-2} \mathrm{yr}^{-1}$ for $\mathrm{N}$ ) do not resemble realistic magnitudes of increased $\mathrm{N}$ availability due to Arctic warming. Indeed, Keuper et al. (2012), reported an increase of $\sim 240 \mathrm{mg} \mathrm{N} \mathrm{m}^{-2}$ in the rooting zone of an Arctic bog following thawing permafrost, which is an order of magnitude lower than our largest annual $\mathrm{N}$ application. Nonetheless, the decoupling of foliar $\mathrm{N}$ and photosynthetic capacity itself is an important observation, since foliar $\mathrm{N}$ (or foliar $\mathrm{N}$ modelled after $\mathrm{N}$ availability) is often used as a (linear) scalar for gross or net $\mathrm{CO}_{2}$ uptake (Thornton et al. , 2007; Kattge et al. , 2009; Zaehle and Friend, 2010). If this decoupling happend at relativley high foliar $\mathrm{N}$ values like in our study, we expect this decoupling to happen also at more moderate increases of foliar N. Therefore, we think that not taking into account this Nphotosynthesis de-coupling at increased $\mathrm{N}$ availability could lead to overestimations of the photosynthetic parameters $\mathrm{V}_{\mathrm{cmax}}$ and $\mathrm{J}_{\max }$ in $\mathrm{CN}$-dynamic models.

As for Arctic stand-scale $\mathrm{CO}_{2}$ exchange, the de-coupled photosynthesis-N relationship in the two Arctic species also implies that the observed increases in gross (and net) $\mathrm{CO}_{2}$ uptake on a ground area basis (such as measured with $1 \mathrm{~m}^{2}$ chambers) after $\mathrm{N}$ and/or $\mathrm{P}$ addition in Arctic tundra are a consequence of increases in LAI, and not a consequence of increased photosynthetic capacity per leaf area (Boelman et al. 2003, Street et al. 2007). Indeed, $75 \%$ of the variability in plot level $\mathrm{CO}_{2}$ uptake amongst Pan-Arctic vegetation types could be explained by radiation levels and LAI alone, without having to consider foliar N levels (Shaver et al. , 2007; 2013). In short, adding N (with P) increases ecosystem level $\mathrm{CO}_{2}$ 
396 uptake in the Arctic tundra, which is facilitated through structural changes in the canopy

397 (increased overall leaf area), while on a leaf level, the photosynthetic capacity remains

398 unchanged.

399

$400 \quad$ Foliar respiration

401 In contrast to photosynthetic parameters, $50 \%$ higher $\mathrm{N}_{\text {area }}$ values corresponded with $50 \%$

402 higher $\mathrm{R}_{\mathrm{d}}$ rates for the $\mathrm{N}+\mathrm{P}$ treatment in B. nana while for $E$. vaginatum respiration was $27 \%$

403 higher with a $15 \%$ increase in $\mathrm{N}_{\text {area }}$ or the $\mathrm{N}+\mathrm{P}$ treatment (Fig. 3e). The lack of increased

404 respiration in the $\mathrm{N}$-only treatment (compared with the $\mathrm{N}+\mathrm{P}$ leaves) of site 1 could be

405 explained by a lower P availability in this treatment, which for example in tropical forest

406 reduces $\mathrm{R}_{\mathrm{d}}$ (Meir et al. 2001), although we do not have foliar $\mathrm{P}$ data to confirm this. Increased

$407 \mathrm{R}_{\mathrm{d}}$ after nutrient addition has been observed in other species as well (Manter et al. 2005), and

408 for B. nana this is a similar observation to Heskel et al. (2012). However, different from the

409 latter study, we only observed a significant increase in respiration after $<20$ years of $\mathrm{N}$ and $\mathrm{P}$

410 addition, and not after a shorter duration of the experiment. Heskel et al. (2012) also observed

411 increased numbers of mitochondrial area (density and size) in E. vaginatum and B. nana after

$412 \mathrm{~N}+\mathrm{P}$ addition. Since investments in mitochondria require more N, this could partially explain

413 why leaves with a higher $\mathrm{N}_{\text {area }}$ have higher $\mathrm{R}_{\mathrm{d}}$ values. Additionally, if the excess foliar $\mathrm{N}$ is

414 invested in more non-mitochondrial proteins, this could cause higher maintenance respiration

415 due to higher protein turnover rates (Penning de Vries 1975).

416 Overall, the results for $\mathrm{V}_{\mathrm{cmax}}, \mathrm{J}_{\max }$ and $\mathrm{R}_{\mathrm{d}}$ show that for the investigated species the

417 different gas exchange parameters cannot be scaled with foliar $\mathrm{N}$ in a similar way. One

418 implication of higher foliar respiration with no increase in C-uptake in the fertilised leaves is

419 that less photosyntate is available for the metabolism in other parts of the plant and

420 ecosystem. Measuring the effects of long and short-term nutrient addition on whole plant 
421 respiration rates (or ecosystem respiration) was beyond the scope of this study. However,

422 long term nutrient addition in the Arctic increases the aboveground biomass more than the 423 belowground (Mack et al. , 2004; Sullivan et al. 2007; Gough et al. , 2012), which can result

424 in relatively less belowground autotrophic respiration than aboveground (on the premise that

425 the respiration of belowground tissue would remain the same). Furthermore, N+P fertilisation

426 and $\mathrm{N}$ deposition can reduce microbial respiration, especially in the rhizosphere in temperate

427 ecosystems, which is a caused by decreased excretion of root exudates and/or decreases in

428 fine microbial biomass (Phillips and Fahey, 2007; Janssens et al. , 2010; Jia et al. , 2010). It is

429 therefore plausible that the increases in foliar respiration because of higher foliar $\mathrm{N}$ are

430 accompanied by decreases in respiration of other ecosystem compartments. We did not

431 measure the respiration rates of the other plant parts so cannot confirm this, but we suggest

432 that future studies on the influence of nutrient supply on Arctic C-budgets and C-fluxes

433 should include gas exchange measurements of all different ecosystem compartments.

435 Conclusions

436 Comparing two sites of different durations in $\mathrm{N}$ and $\mathrm{P}$ addition showed that the PNUE

437 decreases in both $B$. nana and E. vaginatum with increased $\mathrm{N}$ availability, while $\mathrm{R}_{\mathrm{d}}$ increased 438 after long-term (> 20 years) and high dosage $\mathrm{N}$ addition. This either shows that for these two 439 species photosynthesis is either already highly efficient on a lea level scale, or that they

440 become limited for other nutrients with increasing $\mathrm{N}$ and $\mathrm{P}$ availability. This should be taken

441 into account when scaling photosynthetic parameters with foliar $\mathrm{N}$ data (though is probably

442 of less importance when scaling productivity for the Arctic with only LAI). Additionally, the

443 different results for photosynthetic parameters and foliar respiration show that both

444 parameters cannot be scaled with nutrient concentrations in a similar way, urging for

445 modelling both processes separately. Finally, this study showed that short-term effects (1-4 
446 years) of nutrient addition on eco-physiological parameters cannot by default be extrapolated

447 to a decadal time scale. This underlines the importance and value of long-term ecological

448 experiments when we investigate the effects of environmental change on ecological

449 processes.

450

451 Acknowledgements

452 This work was funded by NSF grants from the division of Environmental Biology (Arctic

453 LTER Project) and from the office of Polar Programs (Arctic Natural Sciences, Arctic

454 Systems Science). We would also like to thank the Toolik Lake Field Station and the Arctic

455 LTER project (NSF-DEB-1026843) for logistical support.

456

457 References

458 Azcón- Bieto J and Osmond CB (1983) Relationship between photosynthesis and respiration

459 - the effect of carbohydrate status on the rate of $\mathrm{CO}_{2}$ production by respiration in darkened

460 and illuminated wheat leaves. Plant Physiology 71: 574-581

461 Bauer GA, Bazzaz FA, Minocha R, Long S, Magill A, Aber J, Berntson GM (2004) Effects

462 of chronic $\mathrm{N}$ additions on tissue chemistry, photosynthetic capacity, and carbon sequestration

463 potential of a red pine (Pinus resinosa Ait.) stand in the NE United States. Forest Ecology

464 and Management 196 (1): 173-186

465 Bernacchi CJ, Singsaas EL, Pimentel C, Portis AR Jr and Long SP (2001) Improved

466 temperature response functions for models of Rubisco-limited photosynthesis. Plant, Cell and

467 Environment 24: 253-259

468 Bernacchi CJ, Portis AR, Nakano H, von Caemmerer S and Long SP (2002) Temperature

469 response of mesophyll conductance. Implications for the determination of Rubisco enzyme 
470 kinetics and for limitations to photosynthesis in vivo. Plant Physiology 130: 1992-1998

471 Bernacchi CJ, Pimentel C and Long SP (2003) In vivo temperature response functions of 472 parameters required to model RuBP- limited photosynthesis. Plant, Cell and Environment 26: $473 \quad 1419-1430$

474 Bobbink R, Hicks K, Galloway J, Spranger T, Alkemade R, Ashmore M, Bustamante M, 475 Cinderby S, Davidson E, Dentener F, Emmett B, Erisman JW, Fenn M, Gilliam F, Nordin A, 476 Pardo L and De Vries W (2010) Global assessment of nitrogen deposition effects on 477 terrestrial plant diversity: a synthesis. Ecological Applications 20: 30-59

478 Boelman NT, Stieglitz M, Rueth HM, Sommerkorn M, Griffin KL, Shaver GR. and Gamon J. 479 A (2003) Response of NDVI, biomass, and ecosystem gas exchange to long-term warming 480 and fertilization in wet sedge tundra. Oecologia 135: 414-421

481 Bret-Harte MS, Shaver GR, Zoerner JP, Johnstone JF, Wagner JL, Chavez AS, Gunkelman 482 RF, Lippert SC, and Laundre JA (2001) Developmental plasticity allows Betula nana to 483 dominate tundra subjected to an altered environment. Ecology 82: 18-32

484 Bret-Harte MS, Shaver GR and Chapin FS (2002) Primary and secondary stem growth in 485 arctic shrubs: implications for community response to environmental change. Journal of 486 Ecology 90: 251-267

487 Britton ME (1966) Vegetation of the Arctic Tundra. In: Hanson, H. P. (ed.) Arctic Biology. 488 Oregon State University Press, pp. 67-130

489 Bubier JR, Smith R, Juutinen S, Moore T, Minocha R, Long S and Minocha (2011). Effects 490 of nutrient addition on leaf chemistry, morphology, and photosynthetic capacity of three bog 491 shrubs. Oecologia: 167:355-368 
492 Chapin FS and Shaver GR (1996) Physiological and growth responses of arctic plants to a

493 field experiment simulating climatic change. Ecology 77: 822-840

494 Chapin FS, Shaver GR, Giblin AE, Nadelhoffer KJ and Laundre JA (1995) Responses of

495 arctic tundra to experimental and observed changes in climate. Ecology 76: 694-711

496 Ellsworth DS and Reich PB (1993) Canopy structure and vertical patterns of photosynthesis

497 and related leaf traits in a deciduous forest. Oecologia 96: 169-178

498 Evans JR (1989) Photosynthesis and nitrogen relationships in leaves of C-3 plants. Oecologia

499 78: 9-19

500 Evans JR and Poorter H (2001) Photosynthetic acclimation of plants to growth irradiance: the

501 relative importance of specific leaf area and nitrogen partitioning in maximizing carbon gain.

502 Plant Cell and Environment 24: 755-767

503 Farquhar GD, Von Caemmerer S and Berry JA (1980) biochemical model of photosynthetic

504 CO2 assimilation in leavesof C 3 species. Planta 149: 78-90

505 Field CB and Mooney HA (1986) The photosynthesis-nitrogen relationship in wild plants. In:

506 T.J, G. (ed.) On the economy of plant form and function. Cambridge University Press, pp.

$507 \quad 25-55$

508 Frey KE, McClelland JW, Holmes RM and Smith LC (2007) Impacts of climate warming and

509 permafrost thaw on the riverine transport of nitrogen and phosphorus to the Kara Sea. Journal

510 of Geophysical Research-Biogeosciences 112

511 Friend A, Geider R, Behrenfeld M and Still C (2009) Photosynthesis in Global-Scale Models.

512 In: Laisk, A., Nedbal, L. and Govindjee (eds.), Photosynthesis in silico. Springer

513 Netherlands, pp. 465-497 
514 Gough L, Moore JC, Shaver GR, Simpson RT and Johnson DR (2012) Above- and

515 belowground responses of arctic tundra ecosystems to altered soil nutrients and mammalian

516 herbivory. Ecology 93: 1683-1694

517 Heskel MA, Anderson OR, Atkin OK, Turnbull MH and Griffin KL (2012) Leaf- and cell-

518 level carbon cycling responses to a nitrogen and phosphorus gradient in two arctic tundra

519 species. American Journal of Botany 99: 1702-1714

520 Hobbie SE, Gough L, Shaver GR (2005) Species compositional differences on different-aged

521 glacial landscapes drive contrasting responses of tundra to nutrient addition. Journal of

522 Ecology 93: 770-782

523 Janssens IA, Dieleman W, Luyssaert S, Subke JA, Reichstein M, Ceulemans R, Ciais P,

524 Dolman AJ, Grace J, Matteucci G, Papale D, Piao SL, Schulze ED, Tang J and Law BE

525 (2010) Reduction of forest soil respiration in response to nitrogen deposition. - Nature Geosci

$526 \quad 3: 315-322$

527 Jia SX, Wang ZQ, Li XP, Sun Y, Zhang XP and Liang AZ (2010) N fertilization affects on

528 soil respiration, microbial biomass and root respiration in Larix gmelinii and Fraxinus

529 mandshurica plantations in China. Plant and Soil 333: 325-336

530 Johnson LC, Shaver GR, Cades DH, Rastetter E, Nadelhoffer K, Giblin A, Laundre J and

531 Stanley A (2000) Plant carbon-nutrient interactions control $\mathrm{CO}_{2}$ exchange in Alaskan wet

532 sedge tundra ecosystems. Ecology 81: 453-469

533 Kattge J, Knorr W, Raddatz T and Wirth C (2009) Quantifying photosynthetic capacity and

534 its relationship to leaf nitrogen content for global-scale terrestrial biosphere models. Global

535 Change Biology 15: 976-991 
536 Keuper F, van Bodegom PM, Dorrepaal E, Weedon JT, van Hal J, van Logtestijn RSP and

537 Aerts R (2012) A frozen feast: thawing permafrost increases plant-available nitrogen in

538 subarctic peatlands. Global Change Biology 18: 1998-2007

539 Li Y, Ren B, Ding L, Shen Q, Peng S and Guo S (2013) Does chloroplast size influence

540 photosynthetic nitrogen use efficiency? PLoS One 8: e62036

541 Mack MC, Schuur EAG, Bret-Harte MS, Shaver GR and Chapin FS (2004) Ecosystem

542 carbon storage in arctic tundra reduced by long-term nutrient fertilization. Nature 431: 440-

$543 \quad 443$

544 Manter DK, Kavanagh KL and Rose CL( 2005) Growth response of Douglas-fir seedlings to

545 nitrogen fertilization: importance of Rubisco activation state and respiration rates. Tree

546 Physiology 25: 1015-1021

547 Matthes-Sears U, Matthes-Sears WC, Hastings SJ and Oechel WC (1988) The effects of

548 topography and nutrient status on the biomass, vegetative characteristics, and gas exchange of

549 two deciduous shrubs on an arctic tundra slope. Arctic Antarctic and Alpine Research 20:

$550 \quad 342-351$

551 McClelland JW, Stieglitz M, Pan F, Holmes RM and Peterson BJ (2007) Recent changes in

552 nitrate and dissolved organic carbon export from the upper Kuparuk River, North Slope,

553 Alaska. Journal of Geophysical Research-Biogeosciences 112 
554 Meir P, Grace J and Miranda AC (2001) Leaf respiration in two tropical rainforests:

555 constraints on physiology by phosphorus, nitrogen and temperature. Functional Ecology

$556 \quad 15(3): 378-387$

557 Meir P, Kruijt B, Broadmeadow M, Barbosa E, Kull O, Carswell F, Nobre A and Jarvi, PG

558 (2002) Acclimation of photosynthetic capacity to irradiance in tree canopies in relation to leaf

559 nitrogen concentration and leaf mass per unit area. Plant Cell and Environment 25: 343-357

560 Niinemets U (2003) Role of foliar nitrogen in light harvesting and shade tolerance of four

561 temperate deciduous woody species. Functional Ecology 11(4): 518-531

562 Niinemets U (2007) Photosynthesis and resource distribution through plant canopies. Plant

563 Cell and Environment 30: 1052-1071

564 Oberbauer SF, Hastings SJ, Beyers JL and Oechel WC (1989) Comparative effects of

565 downslope water and nutrient movement on plant nutrition, photosynthesis, and growth in

566 alaskan tundra. Holarctic Ecology 12: 324-334.

567 Penning De Vries FWT (1975) The Cost of Maintenance Processes in Plant Cells. Annals of

568 Botany 39: 77-92

569 Phillips, R. P. and Fahey, T. J. 2007. Fertilization effects on fineroot biomass, rhizosphere

570 microbes and respiratory fluxes in hardwood forest soils. - New Phytologist 176: 655-664

571 Porra RJ, Thompson WA and Kriedemann PE (1989) Determination of accurate extinction

572 coefficients and simultaneous-equations for assaying chlorophyll-a and chlorophyll-b

573 extracted with 4 different solvents - verification of the concentration of chlorophyll standards

574 by atomic-absorption spectroscopy. Biochimica Et Biophysica Acta 975: 384-394 
575 Sharkey TD, Bernacchi CJ, Farquhar GD and Singsaas EL (2007) Fitting photosynthetic

576 carbon dioxide response curves for C-3 leaves. Plant Cell and Environment 30: 1035-1040

577 Shaver GR, Bret-Harte SM, Jones MH, Johnstone J, Gough L, Laundre J and Chapin FS

578 (2001) Species composition interacts with fertilizer to control long-term change in tundra

579 productivity. Ecology 82: 3163-3181

580 Shaver GR and Chapin FS (1980) Response to fertilization by various plant-growth forms in

581 an alaskan tundra - nutrient accumulation and growth. Ecology 61: 662-675

582 Shaver GR and Chapin FS (1986) Effect of fertilizer on production and biomass of tussock

583 tundra, Alaska, USA. Arctic and Alpine Research 18: 261-268

584 Shaver GR and Chapin FS (1991) Production - biomass relationships and element cycling in 585 contrasting arctic vegetation types. Ecological Monographs 61: 1-31

586 Shaver GR and Chapin FS (1995) Long-term responses to factorial, NPK fertilizer treatment

587 by alaskan wet and moist tundra sedge species. Ecography 18: 259-275

588 Shaver GR, Johnson LC, Cades DH, Murray G, Laundre JA, Rastetter EB, Nadelhoffer KJ

589 and Giblin AE (1998) Biomass and $\mathrm{CO}_{2}$ flux in wet sedge tundras: Responses to nutrients,

590 temperature, and light. Ecological Monographs 68: 75-97

591 Shaver GR, Rastetter EB, Salmon V, Street LE, van de Weg MJ, Rocha A, van Wijk MT

592 (2013) Pan-Arctic modelling of net ecosystem exchange of $\mathrm{CO}_{2}$. Philosophical Transactions

593 of the Royal Society B. (in press).

594 Sims DA and Gamon JA (2002) Relationships between leaf pigment content and spectral

595 reflectance across a wide range of species, leaf structures and developmental stages. Remote

596 Sensing of Environment 81: 337-354 
597 Street LE, Shaver GR, Williams M and Van Wijk MT (2007) What is the relationship

598 between changes in canopy leaf area and changes in photosynthetic CO2 flux in arctic

599 ecosystems? Journal of Ecology 95: 139-150

600 Thornton PE, Lamarque JF, Rosenbloom NA and Mahowald NM (2007) Influence of carbon-

601 nitrogen cycle coupling on land model response to $\mathrm{CO} 2$ fertilization and climate variability.

602 Global Biogeochemical Cycles 21: GB4018

603 Van Heerwaarden LM, Toet S and Aerts R (2003) Nitrogen and phosphorus resorption

604 efficiency and proficiency in six sub-arctic bog species after 4 years of nitrogen fertilization.

605 Journal of Ecology 91: 1060-1070

606 Van Wijk MT, Williams M and Shaver GR (2005) Tight coupling between leaf area index

607 and foliage $\mathrm{N}$ content in arctic plant communities. Oecologia 142: 421-427

608 von Caemmerer S (2000) Biochemical models of leaf photosynthesis. CSIRO Publishing

609 Wullschleger SD (1993) Biochemical limitations to carbon assimilation in $\mathrm{C}_{3}$ Plants-A

610 retrospective analysis of the $\mathrm{A} / \mathrm{Ci}$ curves from 109 species. Journal o Experimental Botany

$611 \quad 44: 907-920$

612 Zaehle S and Dalmonech D (2011) Carbon-nitrogen interactions on land at global scales:

613 current understanding in modelling climate biosphere feedbacks. Current Opinion in

614 Environmental Sustainability 3: 311-320

615 Zaehle S and Friend AD (2010) Carbon and nitrogen cycle dynamics in the O-CN land

616 surface model: 1 . Model description, site-scale evaluation, and sensitivity to parameter

617 estimates. Global Biogeochem. Cycles 24: GB1005 
618 Zamin TJ and Grogan P (2012) Birch shrub growth in the low Arctic: the relative importance 619 of experimental warming, enhanced nutrient availability, snow depth and caribou exclusion. 620 Environmental Research Letters 7

621 
622 Table 1. Overview of the nutrient addition treatments and their codes from the two different

623 sites used in this study.

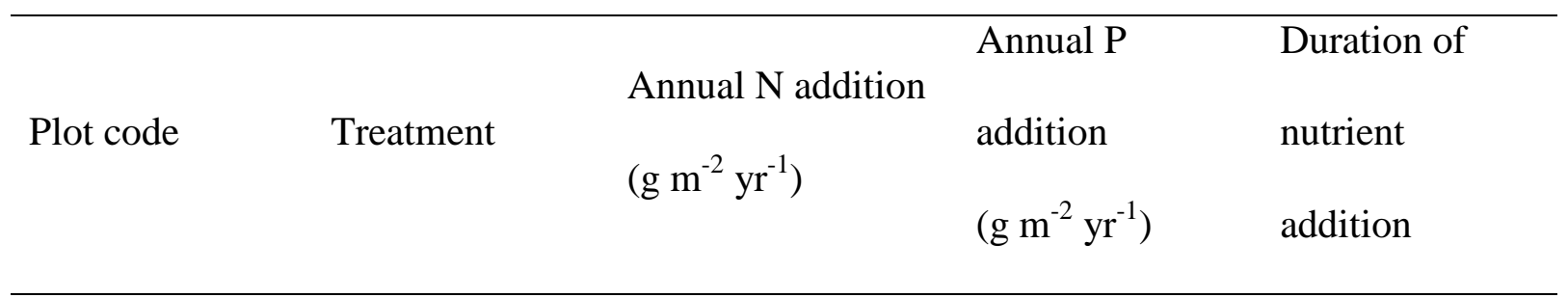

Site 1

$\begin{array}{lllcl}\text { CT } & \text { Control } & 0 & 0 & 0 \text { years } \\ \text { NP } & \text { N + P addition } & 10 & 5 & 22 \text { years } \\ \text { N } & \text { N addition } & 10 & 0 & 22 \text { years } \\ \text { P } & \text { P addition } & 0 & 5 & 22 \text { years }\end{array}$

Site 2

$\begin{array}{lllcc}\text { CT } & \text { Control } & 0 & 0 & 0 \text { years } \\ \text { F10 } & \text { N + P addition } & 10 & 5 & 5 \text { years } \\ \text { F05 } & \text { N + P addition } & 5 & 2.5 & 5 \text { years } \\ \text { YR1 } & \text { N + P addition } & 10 & 5 & 6 \text { weeks (first }\end{array}$

624

625 


\section{Figure legends}

627 Fig. 1 Diurnal average relative received PAR at three different canopy positions in the CT 628 and N+P plot of Site 1 throughout the day from 10 -30 July 2011 (left panes) ( \pm standard 629 error, $\mathrm{n}=21$ ), and the average received PAR per day (right panes).

630

631 Fig. 2 Foliar $\mathrm{N}$ on a mass and area basis per species and per site \pm standard error $(\mathrm{n}=8)$.

632 Asterisks indicate a significant difference of a treatment from the control for that site and species $(*=P<0.05, * *=P<0.01, * * *=P<0.001)$. Abbreviations of the treatments are as in

634 Table 1. $(\mathrm{CT}=$ control, $\mathrm{P}=$ phosphorus addition only, $\mathrm{N}=$ nitrogen addition only, $\mathrm{NP}=$ 635 phosphorus and nitrogen addition, YR1 = first year of nutrient addition, F10 $=10 \mathrm{~g} \mathrm{~N} \mathrm{~m}^{-2} \mathrm{yr}^{-}$ $636 \quad$, F05 $\left.=5 \mathrm{~g} \mathrm{~N} \mathrm{~m}^{-2} \mathrm{yr}^{-1}\right)$

637

638 Fig. 3 Foliar $\mathrm{CO}_{2}$ exchange parameters $\left(\mathrm{V}_{\mathrm{cmax}}, \mathrm{J}_{\max }\right.$ and $\left.\mathrm{R}_{\mathrm{d}}\right)$ and nitrogen content $\left(\mathrm{N}_{\text {area }}\right)$ after 639 long term nutrient addition (Site 1) or short term nutrient addition (Site 2) for E. vaginatum 640 (closed circles) and B. nana (open circles) \pm standard error $(\mathrm{n}=8)$. Abbreviations of the 641 treatments are as in Table 1. Asterisks indicate that for that treatment the Y-axis parameters is 642 significantly different $(P<0.05$, Dunnet's post-hoc test) from the CT treatment of that site and 643 species. Open circles represent B. nana and closed circles E. vaginatum.

644

645 Fig. 4 Foliar chlorophyll $(a+b)$ and leaf mass per area (LMA) and nitrogen content $\left(\mathrm{N}_{\text {area }}\right)$ 646 after long term nutrient addition (Site 1) or short term nutrient addition (Site 2) for $E$. 647 vaginatum (closed circles) and B. nana (open circles) \pm standard error $(\mathrm{n}=8)$. Abbreviations 648 of the treatments are as in Table 1 and Fig. 2. Asterisks indicate that for that treatment the Y649 axis parameters is significantly different $(P<0.05$, Dunnet's post-hoc test) from the CT 
650 treatment of that site and species. Open circles represent B. nana and closed circles $E$.

651 vaginatum.

652

653 Fig. 5 Foliar $\mathrm{N}$ on a mass (a) and area basis (b), $\mathrm{CO}_{2}$ exchange parameters $\left(\mathrm{V}_{\mathrm{cmax}}, \mathrm{J}_{\max }\right)$ on an 654 area basis (c and d), chlorophyll content (e), and leaf mass per area (LMA, f) for B. nana in 655 the NP treatment of Site 1 ( $>20$ years of N+P addition, open circles and dashed line for trend 656 line) and the CT treatment (closed circles, solid line as the trend line). X-axes represent the 657 standardized level of photosynthetic active radiation (PAR) received (1=top canopy). 658 
Figure 1

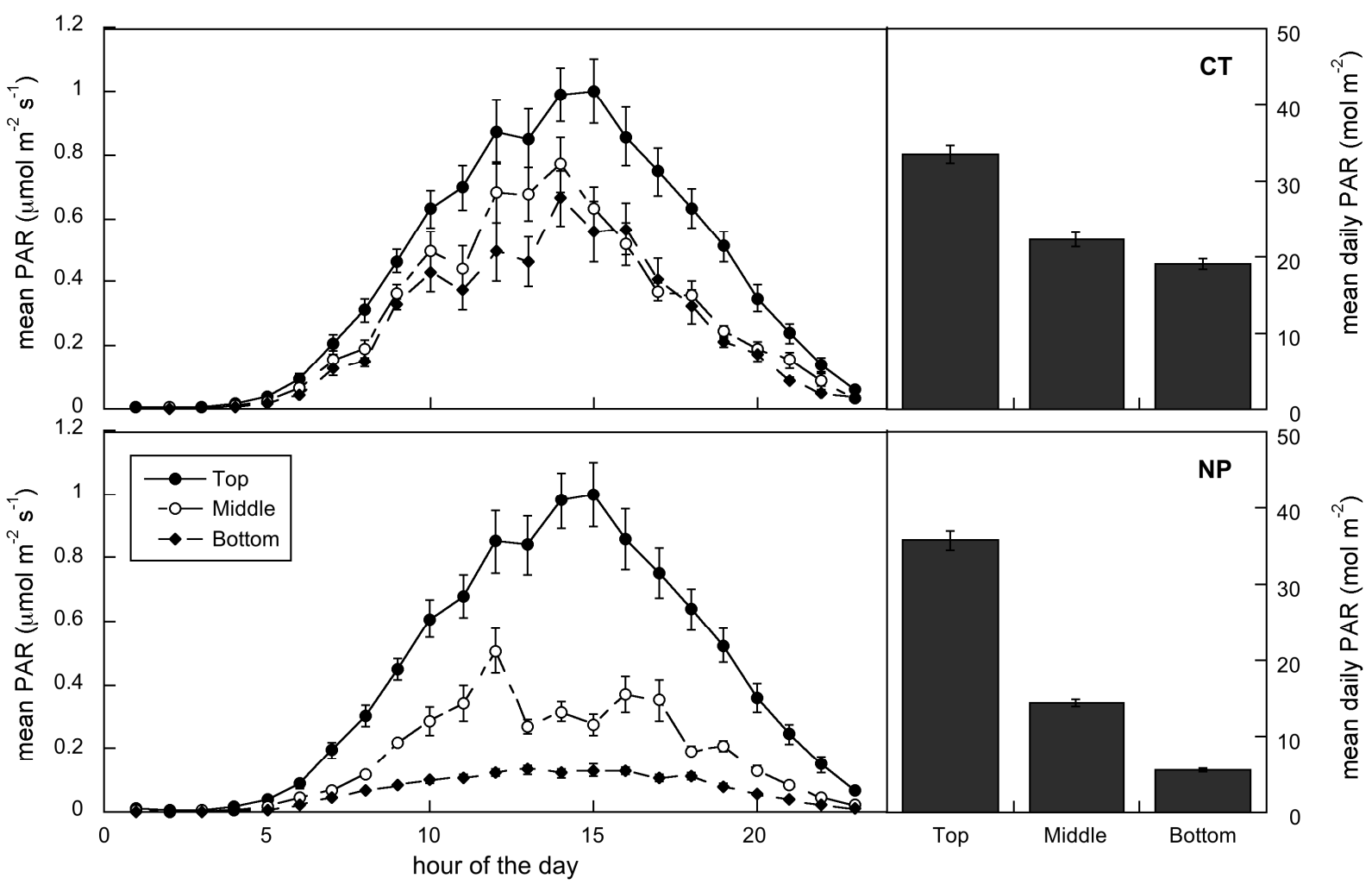

660

661 
662 Figure 2

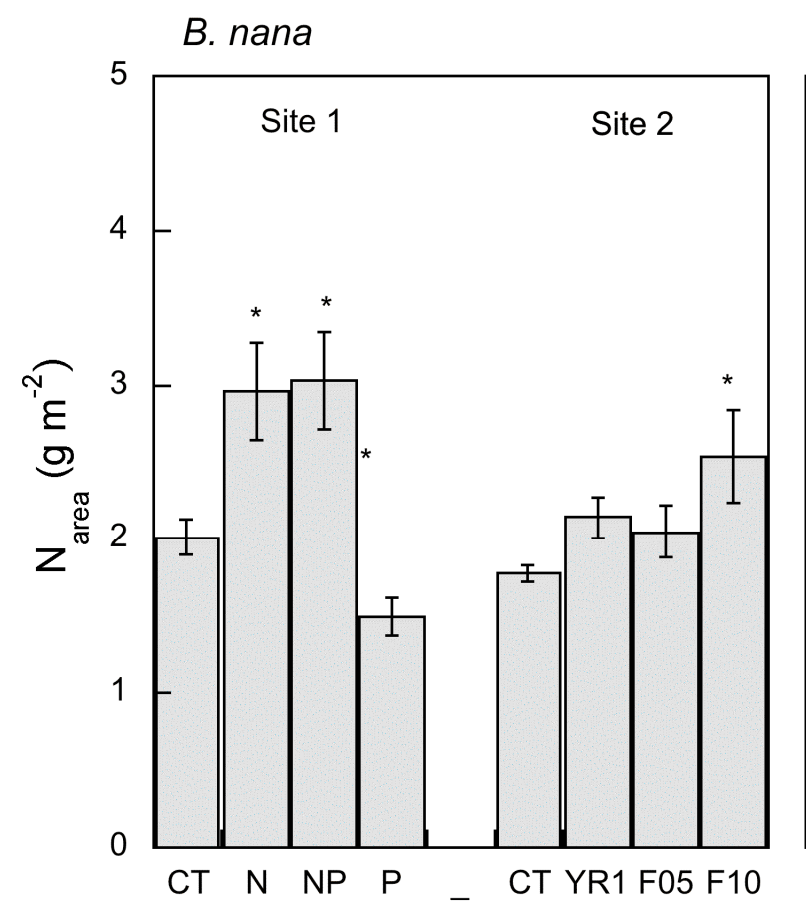

E. vaginatum
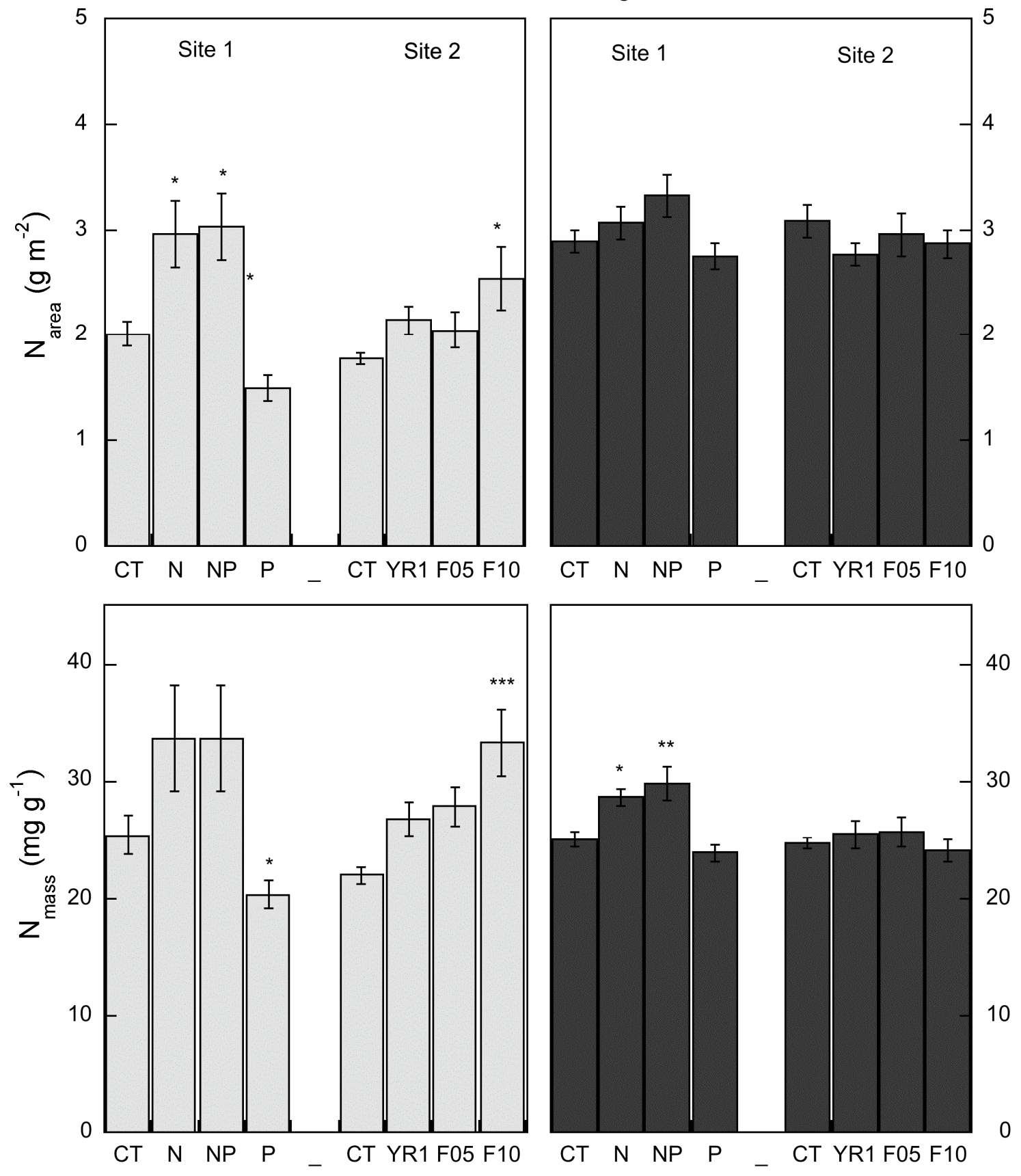

663

664

665 
666 Figure 3

Site 1
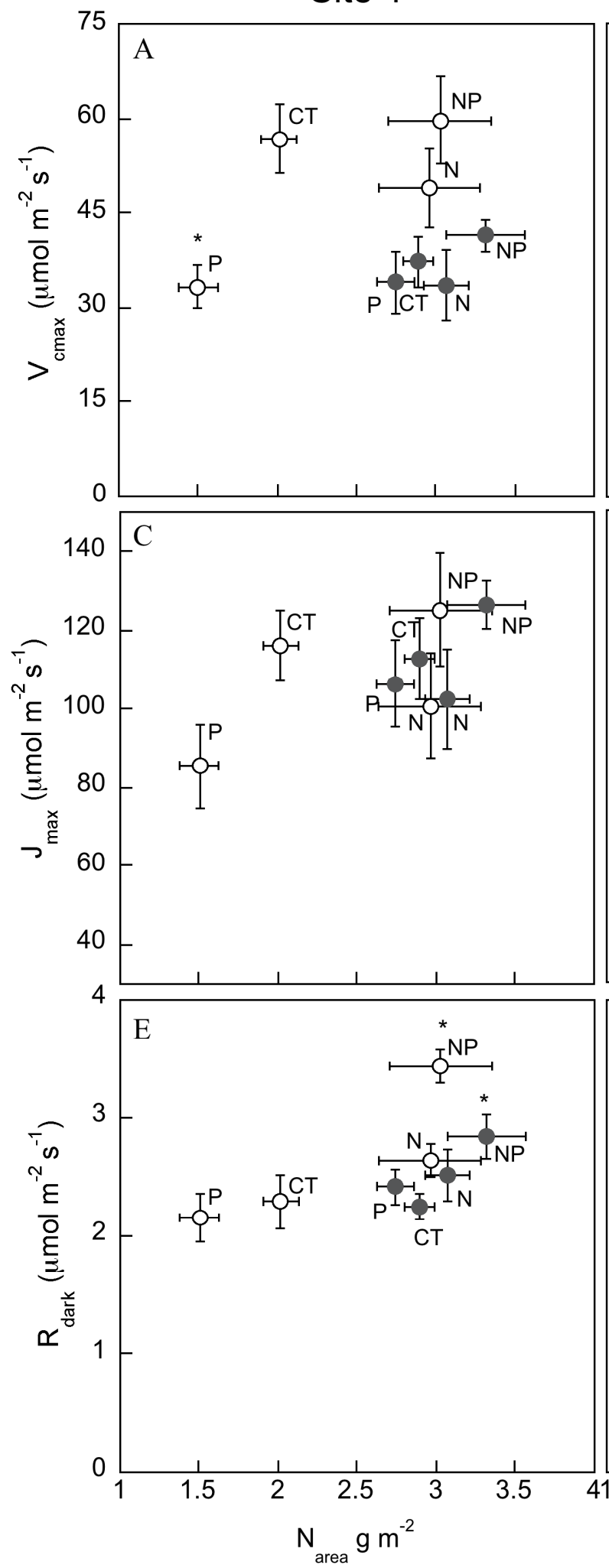

Site 2

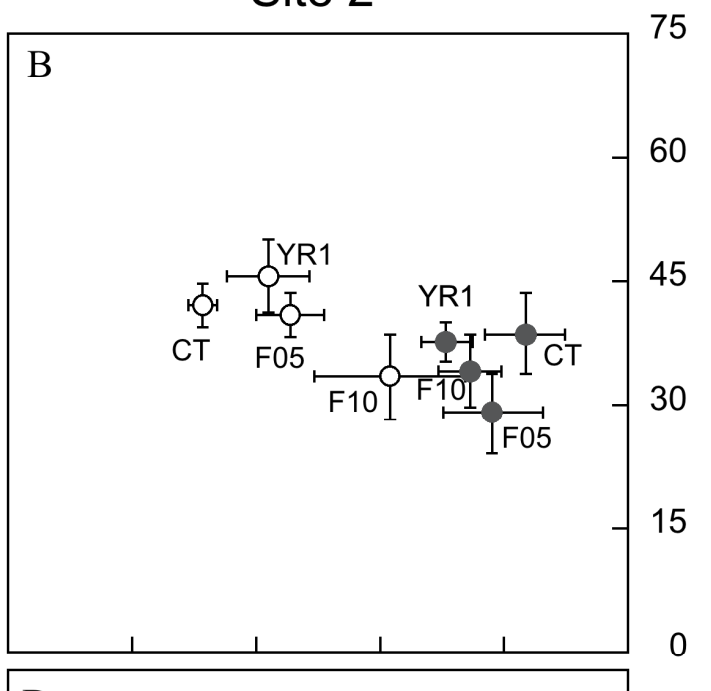

D

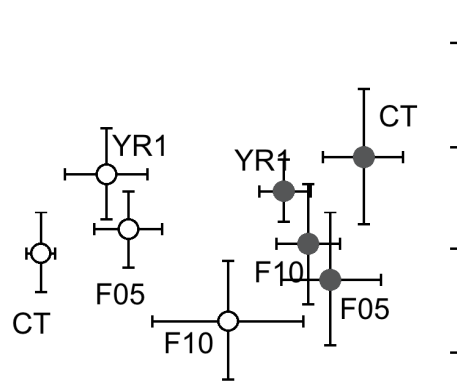

120

100

80

60

40

4

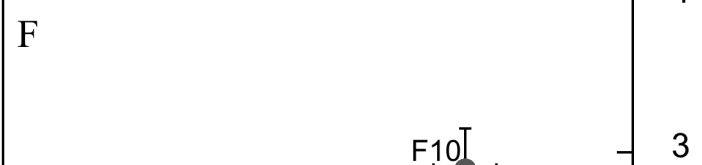

667

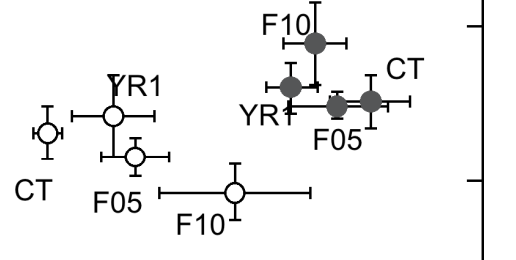


670

671

Figure 4

Site 1
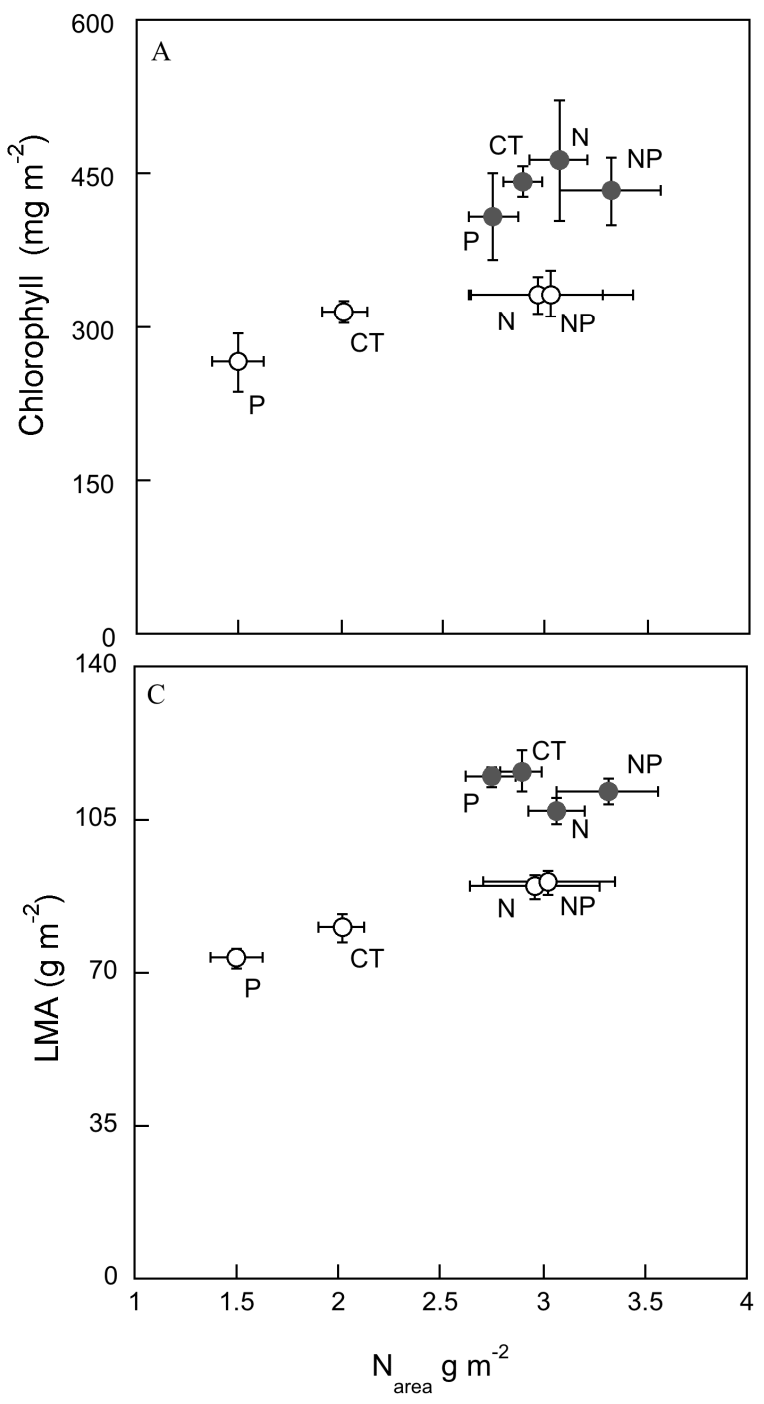

Site 2

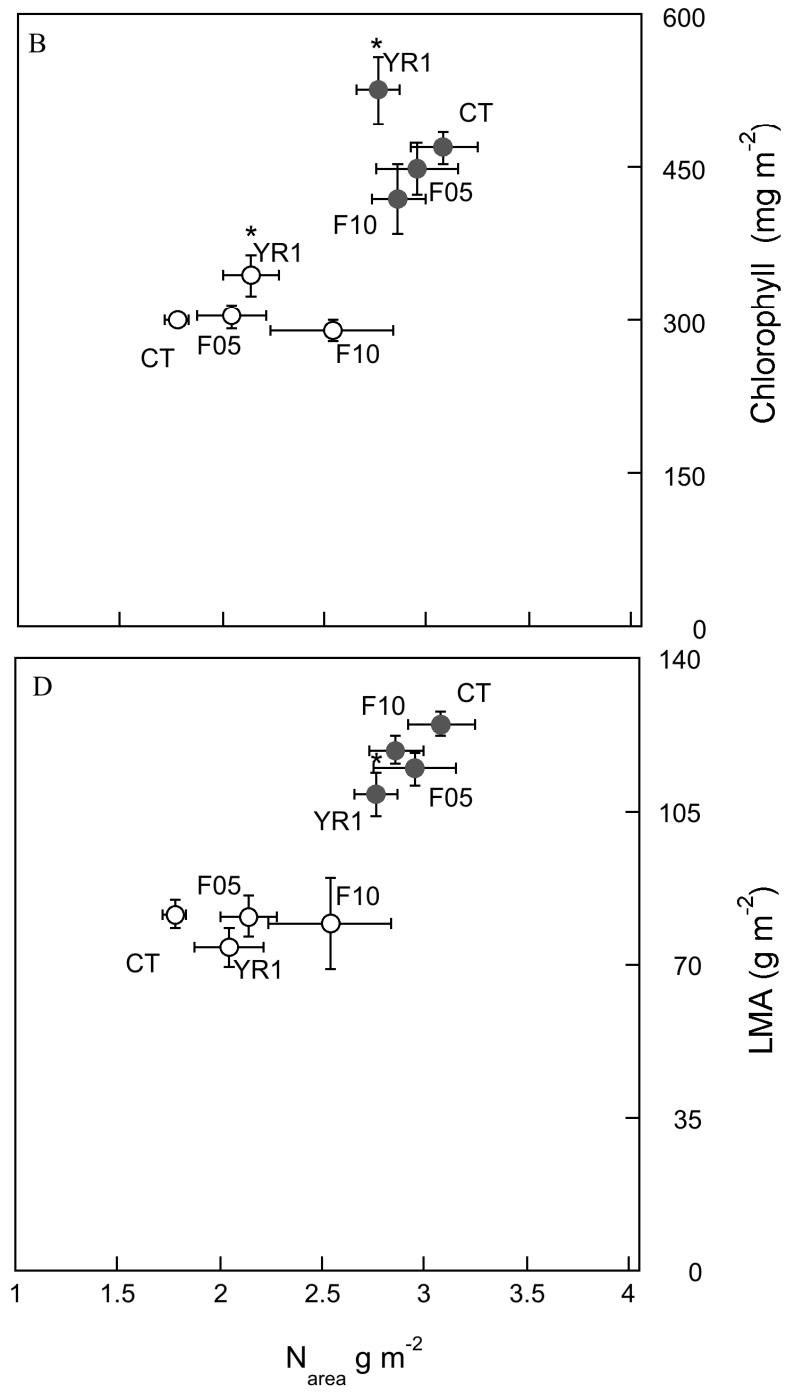

673

674 
$675 \quad$ Figure

676

5
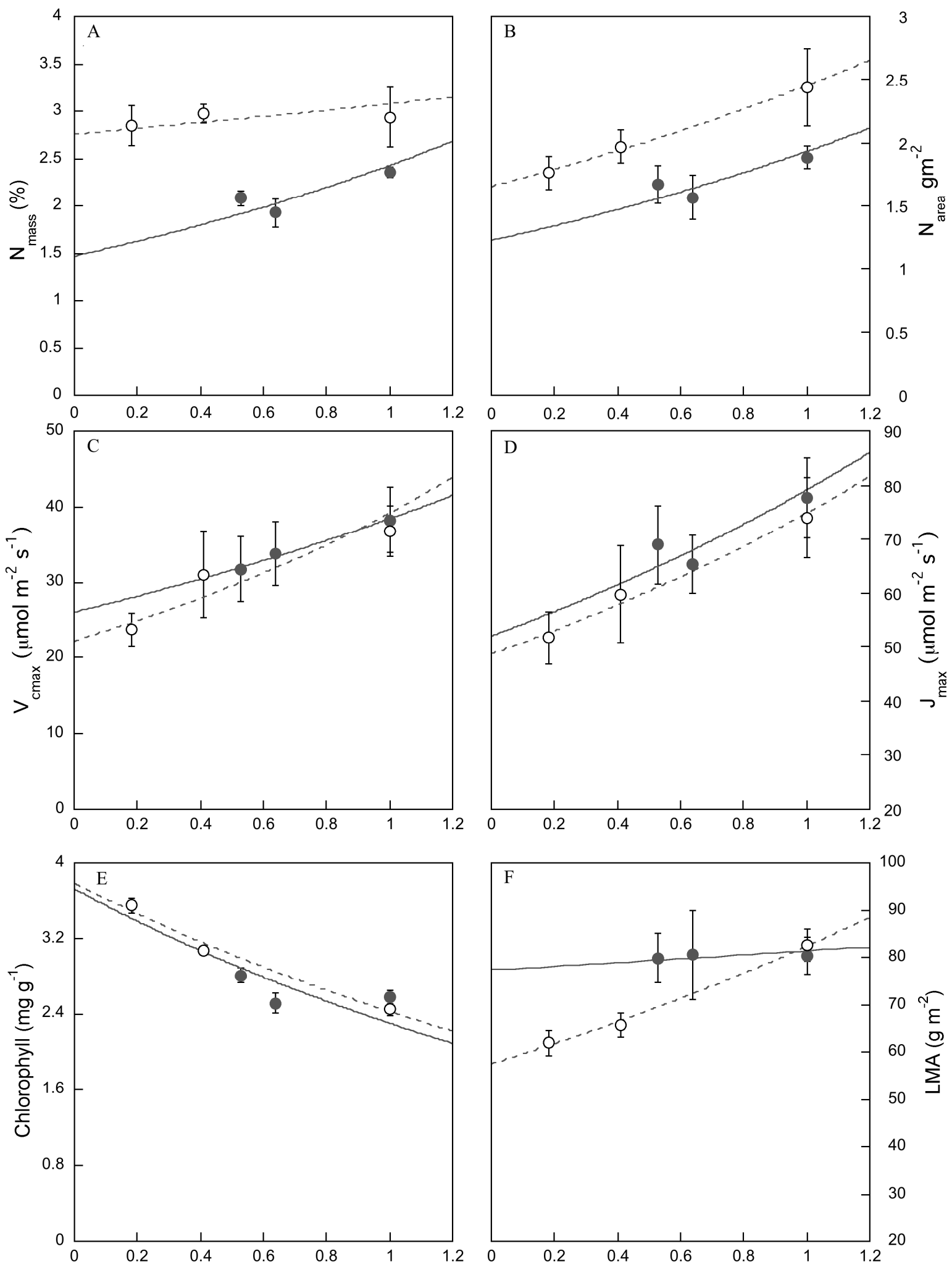

677

Ratio received PAR

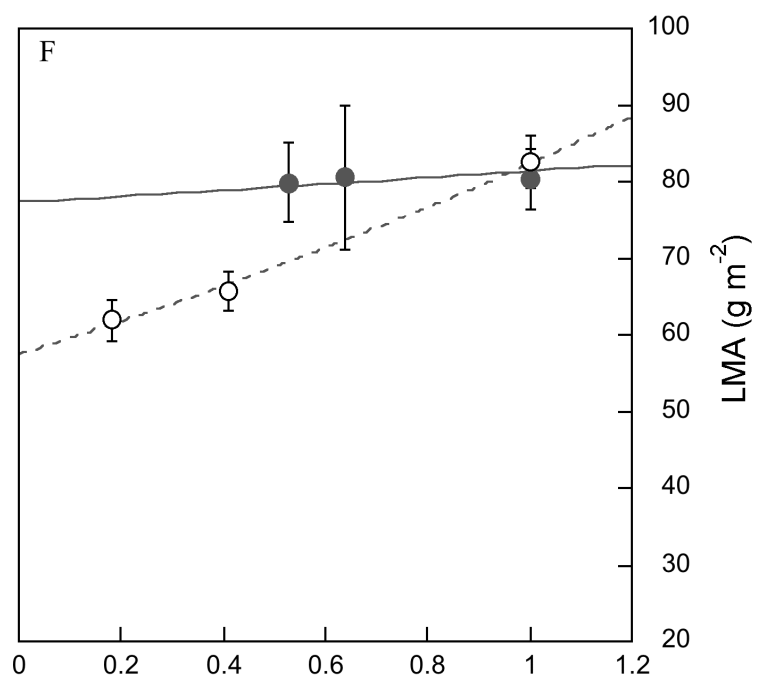

Ratio received PAR 